\title{
A Runic Calendar in the Vatican Library
}

\author{
Carla Cucina (University of Macerata)
}

\begin{abstract}
In 2014, the present author came across a runic calendar - that is a perpetual calendar in which golden numbers and Sunday letters are represented by runes - stored in the repository of the Vatican Latin Collection as item no. 14613. It was known previously to scholars only through a set of photographic reproductions dating back to the mid-1800s now in the Royal Library in Stockholm. This paper is a short and corrected summary of the author's detailed account of the Vatican runic item, which was published in the Miscellanea Bibliothecae Vaticanae 22 (2016). This well-preserved artifact, dated 1684 and belonging to the Swedish "rune-book" type, consists of eight small wooden boards carved on both sides, bound together by a cord passing through two holes near one end. Both the contents of the calendar and its structure and overall style allow an identification of its origin as belonging to the post-medieval Swedish production in the Baltic area, more specifically in the Swedish settlements in present-day Estonia. Interesting analytic cues derive from the first account of the calendar as being stored in Bibliotheca Barberina in Rome, while a comparative investigation of the few rune-book calendars from Estonia that we know of shows that the Vatican item is original in some formal aspects and very attentive in responding to calendar issues and Swedish models. The feasts recorded with symbols in the calendar conform to the Ábo diocese; the holiday marks agree with the Swedish popular tradition, but are occasionally re-interpreted; various onomastic initials, owner's or identification marks (bomärke) and the so-called Saint Peter's game are cut on the cover pages of the rune-book.

Keywords: runic calendar, time-reckoning, calendar runes, post-medieval runic inscriptions, Estonian Swedes, saint's days and feast symbols, Barberini's library, Saint Peter's game
\end{abstract}

Tn the spring of 2014, while working on my latest project in the manuscript section of the Vatican Library in Rome, I came across a post- 
medieval runic calendar known previously to scholars only through a set of photographic reproductions dating back to the middle of the 1800s (the Royal Library, i.e. Kungliga Biblioteket, Stockholm, Fm 70b). Some years prior to my discovery, Sven-Göran Hallonquist had tried, unsuccessfully, to locate the runic calendar reproduced in the photographs so that he could register and examine the piece for inclusion in his plans for publication of the entire vast corpus of epigraphic runic calendars within the Runstavsprojekt (rune-stave project) at the Swedish National Heritage Board/Royal Swedish Academy of Letters, History and Antiquities (Riksantikvarieämbetet/Vitterhetsakademien) and the Nordic Museum (Nordiska museet) in Stockholm. With his assistance in the Royal Library archives, I was able to confirm that the newly found runic calendar in the Vatican Library was in fact that "lost" artifact.

The article here was commissioned by the editors of Futhark, who requested me to compose a short summary in English of my ninety-page article in Italian about this same topic (Cucina 2016a) such that the contents of my detailed account would be more easily available to runologists and other interested readers. For more complete documentation of the artifact (photographs, drawings, discussion, etc.), I refer to the original presentation. Some mistakes and misunderstandings in that article are tacitly corrected here. Corrections were based primarily on suggestions made by the editors and one of the peer reviewers, whom I wish to thank here for their thorough consideration of a number of crucial graphic and external data concerning this unfamiliar and comparatively obscure class of runic calendars.

The runic calendar (see fig. 1) is stored in the repository of the Vatican Latin Collection (Fondo Vaticano latino) as item no. 14613 (Città del Vaticano, Biblioteca Apostolica Vaticana, Vat. lat. 14613). It is a well-preserved, remarkable artifact, belonging to the Swedish "rune-book" type, i.e. a runic calendar consisting of a number of small wooden or ivory boards (usually six to eight) rather than one long stick. Bound together by a cord passing through two holes near one end, these tablets constitute a perpetual calendar in which golden numbers and Sunday letters are represented by runes. (For general presentations of Swedish runic calendars, often called runstavar 'rune-staves; runic calendar sticks' in Swedish, see particularly Lithberg 1921; 1932; 1953, 57-104; Liebgott 1973; Hallonquist 1994.) It is dated 1684 . The contents of the calendar and its structure and overall style allow an easy identification of its origin as belonging to the post-medieval Swedish production in the Baltic area, more specifically in the Swedish settlements in present-day Estonia (see below). 


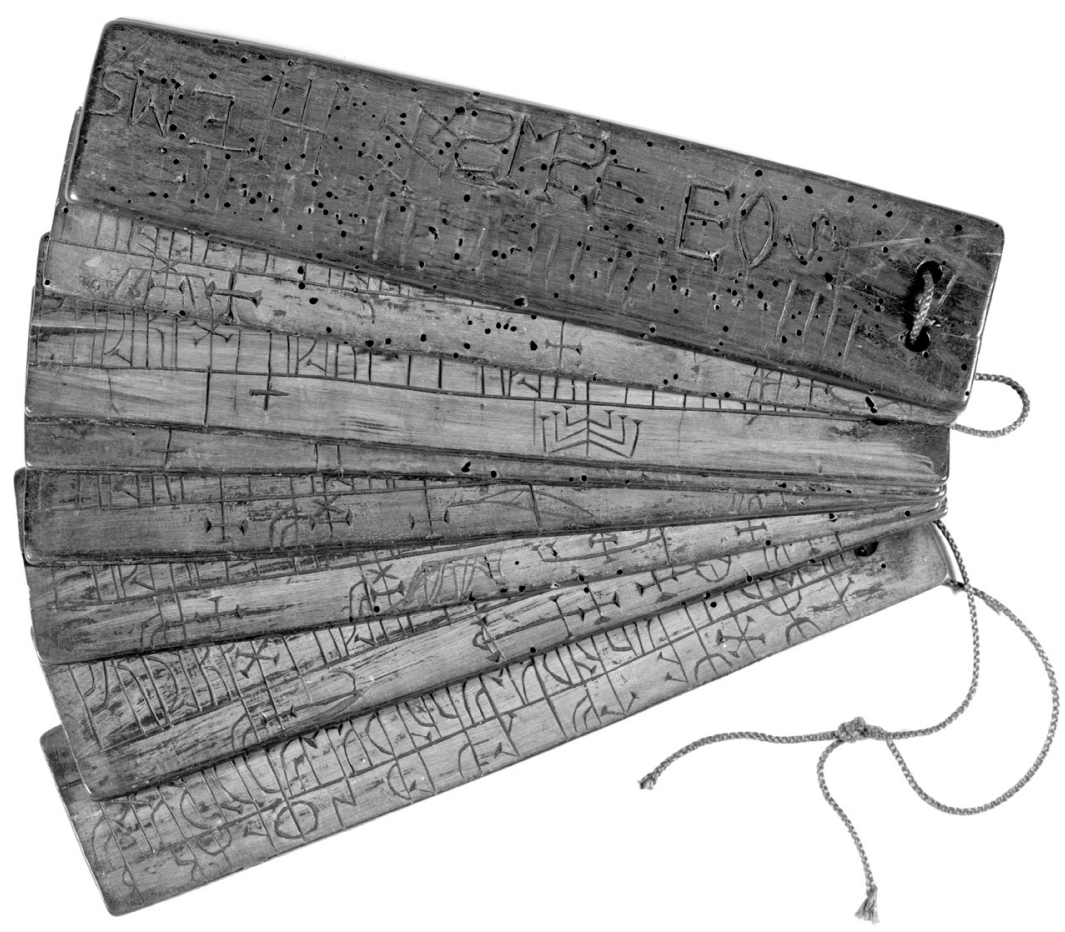

Fig. 1. The runic calendar from Estonia in the Vatican Library (Città del Vaticano, Biblioteca Apostolica Vaticana, Vat. lat. 14613). ( 2017 Biblioteca Apostolica Vaticana. Reproduced by permission of Biblioteca Apostolica Vaticana, with all rights reserved.

The Vatican rune-book calendar comprises eight rectangular wooden boards, each being approximately $233 \mathrm{~mm}$ long, 50 to $53 \mathrm{~mm}$ wide and 3 to $4.5 \mathrm{~mm}$ thick; they are all carved on both sides. Fairly modern Arabic numbers written with a sharp pencil appear as a rule at the upper or lower (depending on space) left-hand corner of each side of the boards and give the correct sequence of the "pages". It should be noted, however, that the numbers 9 and 10 on the fifth board are reversed and placed at the lower right-hand corner, and thus that particular tablet must have been turned or inverted when the pagination was added. This is possible because one of the holes for the binding cord is broken all the way to the edge, meaning that it hung in only one cord. The positioning of the modern numbering, except in the case of sides 9 and 10, is correctly oriented for the reading of the runes. They are read in the standard way, from left to right. The runes for golden numbers are then in the line above the runes 
for days of the week (Sunday letters), with the same orientation, whereas the symbols for church holidays and peasant feasts are below and are therefore generally inverted in relation to the runes in the other two lines. The correct foliation of the rune-book is confirmed by the original notches (one to eight) cut in the lower outer (short) edge of each board.

Runes and calendar (holiday) marks are clear and easily readable; noncalendrical carvings on the cover boards of the booklet, which provide external data and contextual notes, are also clean-cut, even if a straightforward interpretation of their meaning may occasionally not be possible. The uniformity of the calendrical carvings indicates that the calendar itself is the work of a single carver. The $\mathrm{V}$-shaped cuts were probably, as usual, produced by two cuts with the knife. Although an initial guideline incision with the knife perpendicular to the surface could have been made in order to place each of the figures correctly, the final forms were carved by cutting twice, with the knife at an oblique angle to the right and to the left side of the line to be inscribed (Sven-Göran Hallonquist, pers. comm., 3 July 2017, after reading the manuscript for this article). A different, possibly later hand carved the date "ANNO 1684" on board 1r. On the outer surfaces, $1 \mathrm{r}$ and $8 \mathrm{v}$, several apparently different and in part probably later hands incised a number of inscriptions (see below).

The material is apparently oak. Following routine procedure at the Biblioteca Apostolica Vaticana, where laboratory analysis is only performed when it is considered essential for research, no attempts have been made to determine the type of wood. My identification is based on empirical examination and comparison with runic typological analogues of similar provenance and date. The entire surface of each tablet has been treated with some substance, perhaps a smooth brown oil or wax, which has collected in the fresh end-grain of the carving incisions and given them a darker color. Although practically all the runic calendars from Sweden and Finland that Hallonquist has examined were impregnated with beeswax, usually dissolved in turpentine, he was unable to determine what surface treatment was used for the Estonian runic calendars but thought it looked like it was based on tar (pers. comm., 3 July 2017 and 28 June 2014 respectively). The boards are in comparatively good condition, but for some of them the wood is worn around the two binding holes and along the outer edges, and occasionally (from tablets 2,5 and 7) some fragments are missing, all this attesting to the fact that the calendar most likely was in use for a long time.

The only, very brief description of the runic calendar in the Biblioteca Apostolica Vaticana catalogue entries (see Bertolini 1977, 105) provides 
no explanation of how it made its way into the Vatican collections. Nevertheless, the short record in the Royal Library, Stockholm (see above), has proved of primary importance for tracing at least some of the modern antiquarian events concerning its acquisition.

In the first months of 1772, during his grand tour abroad, the Swedish philologist and Orientalist Jacob Jonas Björnståhl visited Rome. At that time, he was carrying on an extensive correspondence with Carl Kristoffer Gjörwell (the elder), the Royal Librarian in Stockholm, who as a rule published his friend's epistolary accounts in the contemporary journal Samlaren and in his own literary news journal Allmänna Tidningar as he received them, and eventually collected and published all Björnståhl's letters in six volumes, issued in Stockolm between 1780 and 1784, soon after Björnståhl's death in 1779 (see Björnståhl 1780-84). In a letter dated 18 March 1772, dealing with Roman libraries, he gives a detailed account of the Bibliotheca Barberina, then a renowned collection of more than 9000 manuscripts stored in Palazzo Barberini. Among various remarkable items, above all pertaining to Greek and other Oriental languages, he mentions a curious, neglected item as included in the library collection (vol. 1: $358 \mathrm{f}$. [letter 29], with a few orthographic corrections):

Jag har ock därstädes sedt ... äfven et gammalt Rune-Calendarium, som ingen härstädes förstod, innan jag gaf dem nyckeln. Runorne äro til figurerne olika med de i Sverige befintelige, så väl de almänna, som Helsing-Runorne.

(I have there seen ... in addition an old rune-calendar, which no-one here understood until I gave them the key. The runes are in their shapes unlike those occurring in Sweden, both the usual ones, as well as the Hälsinge-runes.)

Björnståhl was easily able to identify his find as a traditional (gammalt 'old') runic calendar, even if, as he points out, the graphic system employed was different from both the Swedish standard futhark and the staveless runes (stavlösa runor, also called hälsingerunor in Swedish since they are mainly found in the province of Hälsingland). He misses the point, however, when he states that these runes have nothing in common with the staveless runes, especially since that particular form variant of younger runes is not recorded as ever being used for calendar symbols in Sweden. Nevertheless, this is interesting evidence of the lively debate among scholars in the academic circle of Uppsala, where in 1675, after long discussions and much debate, Magnus Celsius (162178) had deciphered the peculiar staveless rune-row. In Uppsala, by the second half of the following century, Olof Celsius (senior, 1670-1756) had 
completed and eventually published his father's runic studies (see Jansson 1983; Cucina 2003). Björnståhl himself had started his teaching career, as lecturer (adjunkt) and then professor of Oriental languanges, at the same university.

It should, however, be mentioned that the fashion of runic (i.e. runic calendar) walking sticks (vandringsstavar, cf. Hallonquist 1994, 177-79) had been one of the curious products of Swedish Gothicism or Gothic revival in the 1600s. Even if the runic calendar in the Bibliotheca Barberina was a far less common, "pocket" kind of "rune-stave", Björnståhl had no difficulty in recognizing its formal pattern, based on three horizontal lines over one another of calendar signs, covering the whole year (see fig. 2): in the middle, runes for the Sunday letters; above or below (here above), runes for the golden numbers; below or above (here below), marks and symbols for holidays.

At the end of the 1600s, the library in the Palazzo Barberini was considered the second largest book and manuscript collection in Rome (see Mabillon and Germain 1687, 133; de Montfaucon 1702, 210), and was visited by scholars from all over Europe. At the beginning of the 1800s, Friederich Blume wrote that it was open to the public at least two halfdays a week (Blume 1830, 134), and that there, among other interesting items, he had seen the runic calendar briefly described by Björnståhl (p. 136, note 11). Further evidence that this rune-book was still in Rome in the later half of the 1800 s comes from the above-mentioned photos preserved in the Royal Library in Stockholm (see above), since these were sent to Oscar Dickson (1823-97) in Göteborg, who eventually presented them to King Oscar II of Sweden in December 1874 (Hallonquist, pers. comm., 28 June 2014).

The Bibliotheca Barberina was acquired by the Vatican Library in 1902 (see Bignami-Odier 1934, 223 f.), but how or why the runic calendar entered the Vatican Latin Collection remains a mystery. To my knowledge, corroborated by Paolo Vian's overview of the history of the Barberini Collection in the Biblioteca Apostolica Vaticana (in D'Aiuto and Vian 2011, 336-51), it is the only item originally belonging to the Barberini Library that was not put into the Vatican Library's Barberini Collection. I could only discover that it was given a first (no. 10212) and then a new (current no. 14613) shelf mark in the Vatican Latin Collection, which means that grounds for its placement in that collection appear to have been at least somewhat doubtful in the early 1900s.

The Vatican runic calendar's general outline stems from a long tradition. The threefold horizontal, continuous or "linear" pattern reproduces the 
oldest model of the runic calendar, namely the well-known Nyköping find from around 1250 or soon thereafter (see Svärdström 1966). This model is continued in the several hundreds of later Swedish examples, mostly meant for illiterate people, preserved in public and private Scandinavian collections (Hallonquist 1994). The particular mixture of crosses, attributes of saints, natural symbols and agricultural tools to mark holidays is characteristic of the common later Swedish runic calendars in the form of sticks and single or multiple boards (Lithberg 1921, 1932). The overall design and partitioning of the calendar is strongly reminiscent in particular of the wood or ivory rune-book calendars of the Lappish/Sami (Granlund and Granlund 1973) or Baltic (Jansson 1962) traditions.

As to the graphic system employed for calendar purposes, forms of the first seven runes of the younger futhark correspond to the roman letters ABCDEFG for the days of the week (Latin litterae dominicales, i.e. Sunday letters; used in conjunction with the solar cycle of twenty-eight years). Forms of the whole series of the sixteen-character futhark, augmented by three extra, fabricated runes $(\mathcal{\uparrow}, \mathcal{\Psi}$, and $\Phi$, called respectively árlaug, tvimaðr and belgporn) correspond sequentially to the individual golden numbers from one to nineteen (Latin aureus numerus, Old Norse primstafr, Swedish primstav; used to specify the Metonic or moon cycle of nineteen years).

The inner side of the first tablet (1v) presents in full the runic system employed in the booklet (see below, and see fig. 3): the great solar cycle, where double Sunday letters denote leap years, and the Metonic cycle. The Church calendar, whose primary function was calculating the date of Easter, was based on the Tabula Paschalis (Easter table); in this table, Sunday letters crossed with golden numbers and indicated a certain year. Here, the beginning of the twenty-eight-year solar cycle is marked as pertaining to the (leap) year 1520, since the Sunday letters G/A (runes $* / F$, i.e. $\mathbf{h} / \mathbf{f}$ ) correspond to this year on the 532-year or great Easter table (see Pfaff 1946, appendix, numeric table 8). The fact that this runic book is dated 1684 means only that it was carved according to an older model, which, by the way, must have been more or less the rule with post-medieval Swedish runic calendars of any kind.

The runes on runic calendar sticks have often acquired forms that deviate somewhat from the standard medieval forms. For instance, the $o$-rune, which in high and late medieval times basically had two branches downward to the left from a vertical stave, quite frequently has the upper branch pointed upward to the left. This is obviously done so that the branches avoid coming in contact with the pocket on the preceding $p$-rune 

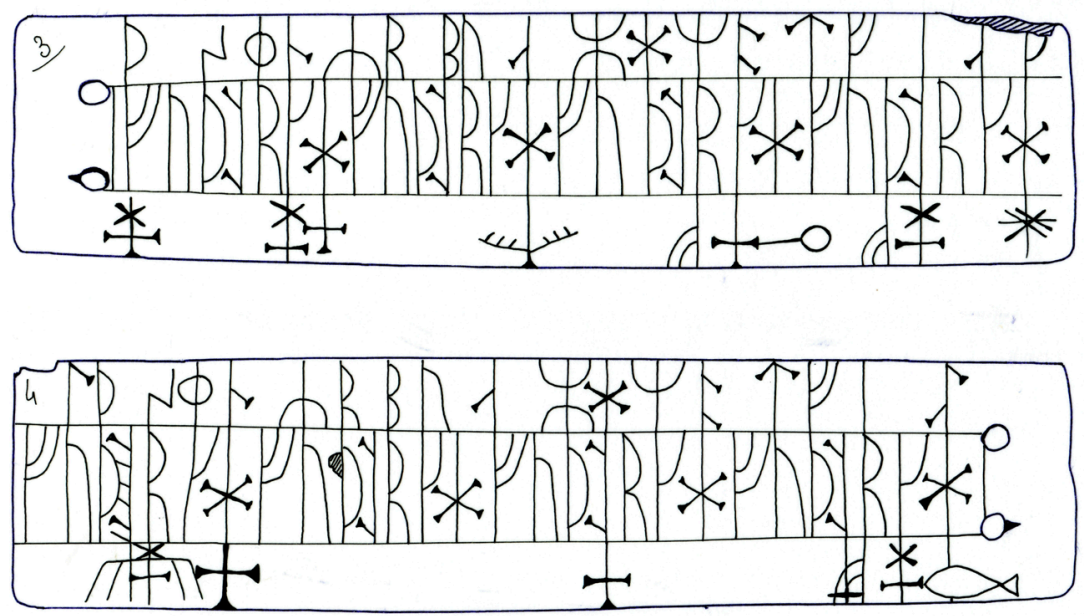

Fig. 2. The Vatican runic calendar from Estonia, tablet 2, with the first part of the calendar itself: $2 \mathrm{r}$ (side 3 ) covering 1 to 28 January and $2 \mathrm{v}$ (side 4 ) covering 29 January to 25 February. Drawing by the author.

when the symbols are carved close together. (This fairly standard deviant form is found in the Vatican calendar.) In addition, single runes can be reversed or inverted (accidentally?), or even all instances of a certain rune in the entire calendar can consistently have such a somewhat deviant shape. Forms that are symmetrical, such as $* \mathbf{h}$, will, of course, show neither reversal nor inversion. Curiously, however, although the runes on the entire Vatican calendar itself have standard orientation (none are reversed, none are inverted, all read from left to right), all the runes in the full presentation of the runic system on $2 \mathrm{v}$ read from right to left, and thus the forms of the runes are reversed in relation to the forms in the calendar itself (see fig. 3 and compare with fig. 2). There is no obvious explanation for this being the case.

The remaining inner pages of the runic booklet $(2 \mathrm{r}-8 \mathrm{r})$ each present Sunday letters for twenty-eight days, i.e. four weeks - except for last, 8r, where there are twenty-nine Sunday letters (this in order to attain the total of 365 days of the Julian year). Thus the annual sequence is divided into thirteen sections. This division is in accordance with traditional Scandinavian time reckoning, which was based on weekly rather than monthly units, as also evidenced by the oldest Icelandic historical (Íslendingabók, ch. Frá misseristali), encyclopedic (Rímtol) and juridical (Grágás) sources (see Brate 1908; Hastrup 1985, 17-49; Janson 2011; cf. Lithberg 1944). 


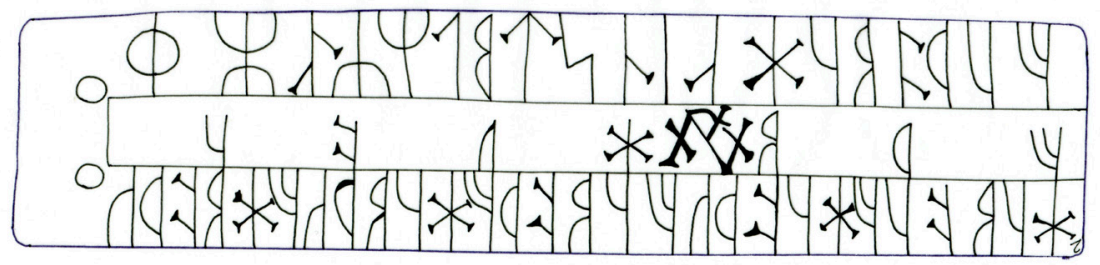

Fig. 3. The Vatican runic calendar from Estonia, tablet $1 \mathrm{v}$, with a full overview of the runic system for the calendar. The lines consist of nineteen golden numbers (runes) at the top for the lunar cycle and repetitions of the seven Sunday letters at the bottom for the solar cycle. The lines inexplicably read from right to left - contrary to all the other tablets in the calendar - and the runes thus appear as reversed in form. Drawing by the author.

Accordingly, on the Vatican rune-book calendar, months are only marked by means of an unornamented perpendicular line cut from the top edge down to the top of the rune for the first day of each month. This is a practice that appears around the middle of the 1600s (Hallonquist, pers. comm., 3 July 2017).

Two lines carved along the length of the broad sides of each tablet divide the available space into three bands of relatively equal width, although the one in the middle is often somewhat wider. The Sunday runes run from left to right in the middle band. Along the upper line, runes for the golden numbers match with some days according to the old series (Latin aureus numerus antiquus). In the lower space, crosses combined with symbols and, on occasion, appropriate indications of the vigils (vigiliae, by a double or triple branched $\mathbf{Y} \mathbf{f}$ for fasta 'fasting') mark the most important holidays of the Church calendar or peasant feasts of the civil year. As a particular trait of the Vatican calendar - shared with no more than a couple of runic calendars in a corpus of about 800 more or less contemporary items (Hallonquist, pers. comm., 28 June 2014) - an ' $x$ ' marks some crosses, namely for those holidays which had not been abolished by the 1571 Church order in Sweden (see 1 January and 6 January as opposed to 7 January on fig. 2; cf. Malmstedt 1994, 59-79, English summary $261 \mathrm{f} . ; 2014)$. This is good evidence for considering the carver (or owner) as well advised and politically correct in calendar matters, and for concluding that he probably worked for (or was) an ecclesiastic.

A comparison of the feasts recorded with symbols in the Vatican calendar with those recorded for various Swedish dioceses reveals that it conforms to the Åbo diocese (cf. Maliniemi 1925). Evidence lies in some feast days that occur on different dates: for instance, St. Henrik 20 (the 
true date of his death) instead of 19 January, St. Margarete 13 instead of 20 July, St. Anne 15 instead of 9 December. Some other holidays, such as the votive mass of the Blessed Virgin Mary (missa votiva de Virgine) on 26 May and the translation of the venerated Finnish national saint, St. Henrik (translatio Henrici, 18 June), which were particularly observed in that see, are duly recorded on the Vatican rune-book.

A comparison with the entire corpus gives specific indications that it was produced by the Swedish settlers in Estonia, whence a small but interesting group of rune-book calendars originate. Runologists have paid little attention to these finds, except as evidence of a very late, unbroken tradition of the runes in the North, especially among farmers. Some relevant remarks about the use of runic calendars as a distinctive Swedish custom among the Estonian Swedes (estlandssvenskar) are, however, to be found in early ethnographic literature concerning Estonian calendar lore (Cucina 2016b; cf. in particular Jansson 1962). In books or articles published by folklorists from the last decades of the 1700 s to the middle of the 1800 s, one can occasionally find enthusiastic descriptions of runic items (now long lost), which are especially useful for defining the typology, date and provenance of this still elusive body of material. A case in point is the now-lost rune-book calendar originating from the Isle of Ósel, today Saaremaa, to which ethnographers in that time period paid special attention (see Hupel 1782, 366-70; Tooke 1799, 216 f.; Urban and Tooke 1812; Russwurm 1855, 169-72). The little calendar appeared carefully drawn in outline (see Hupel 1782, pl. iii; Urban and Tooke 1812, pl. ii; Russwurm and McDonald 1855, pls. xiii-xv) and described in detail with annotated lists of the recorded Church festivals and seasonal or agricultural pivotal points of the folkloric year (Hupel 1782, 367-70; revised English version in Urban and Tooke 1812, 625 f.). Such material, essential to any further research, has been very useful for my analysis of the Vatican item.

Although modern scholarly investigation in this specific niche of Scandinavian calendar lore is both scanty and in need of updating (see, however, the extensive presentation in Jansson 1962), I have been able to rely on Hallonquist's generous assistance with museum archives and private collections in Sweden, as well as on his own inventory draft and unpublished notes about all the runic finds from Estonia that he knows of. A cross-checking of information has led to the identification of a body of fifteen known-not always preserved-runic calendars from Estonia. The present comparison has been based particularly on the following items: the above-mentioned lost rune-book calendar from the Isle of Ósel 
(Saaremaa); two runic books from Gammalsvenskby, Ukraine, originating ultimately from Dagö (Hiiumaa), but both now in Stockholm, namely in Nordiska museet, inv. no. 89901 (dated 1766), and in Ann-Marie Olrog's private collection (eight-page calendar, dated 1827; pers. comm. by Hallonquist, 13 Dec. 2014, and by Hallonquist with Helmer Gustavson, 16 Dec. 2014); Halle, Naturalienkabinett des Waisenhauses, no. 15Q (unknown origin; see Hofe 1942, 137-50, pls. xxiii f. [figs. 57a-b], but there erroneously thought to be a Swedish product from Finland; correct identification in Jansson 1962, $131 \mathrm{f}$., specifically note 11); and finally the lost rune-book calendar reported by Lithberg as located in Zürich in the 1930s (unknown origin; photographic reproduction in Nordiska museet, Lithbergs arkiv, E1:1).

A thorough analysis of the recorded feasts occurring in all these calendars, together with a synoptic view of the symbolic marks employed, confirms a high degree of standardization in content and style for the whole group, but it also shows some deviating formal traits on the part of the Vatican piece. For example, the recurrent mark for St. Mary's various festivals proves original in this class of calendars in that it shows the cross as part of a stylized crown (a usual symbol in the Swedish corpus), instead of the cross within a halo, which seems the rule with the Estonian runic items. Attributes of some of the saints require an unconventional or "popular" reading, based on the pivotal points of the farming or economic year rather than on traditional iconography: a fish for St. Matthias (24 February), a cuckoo for St. Mark (25 March), an ear of rye for St. Erik (18 May), a scythe for St. Olaf (29 July), a ship for St. Matthew (21 September), a scales for St. Michael (29 September), possibly a carding tool instead of the usual book for St. Birgit (7 October), a "goose" for St. Martin (11 November). The carver of the Vatican calendar proves particularly in tune with the Swedish tradition of the runic calendar stick; but even within this established tradition, he can occasionally re-interpret feast marks or create new ones. A case in point is the symbol for St. Martin's day just mentioned, which on the other Estonian calendars is alternatively an attribute of episcopal office (Ösel, both items from Gammalsvenskby [ultimately Dagö] and Halle) or a horse (Zürich), whereas on Swedish runic calendar sticks the most popular sign for Martinmas is a goose. In the Vatican calendar, the mark for St. Martin's feast is a breastbone, thus apparently referring to the folk belief that people could foresee the character of the coming winter from the whiteness versus brownness of the breastbone in the goose roasted for Martinmas (a tradition recorded first in Olaus Magnus's Historia de Gentibus Septentrionalibus, 1555, a 
work which also contains the first printed presentation of Swedish runic calendar sticks).

The front cover of the Vatican rune-book (1r) contains the onomastic initials SMS and EOS, and upside down in respect to them EMS, all constructed on the model "XYs-Son", and in addition marks of ownership or possibly as a maker's "signature" by the rune-carver. Along with these, other capital letters are combined, apparently in monograms $(\mathrm{H}+\mathrm{I}$ or perhaps $\mathrm{H}+\mathrm{T}$, and $\mathrm{E}+\mathrm{T}$ ), and an owner's or identification mark used as a signature or often as a family sign, usually by an illiterate person (bomärke), appears - the same mark as occurs on the verso of the same board where the entire graphic system of the calendar is presented $(1 \mathrm{v}$, see above). Various carvings of several other owner's or identification marks (bomärke) appear on the back cover (8v), along with the date "ANNO 1684" and the onomastic initials MMS. This probably indicates that the calendar passed from hand to hand, so that even the only certain external date (year 1684) may not refer to the original date of production of the calendar. Of course, SMS, EMS and MMS could all be sons of some particular M., and thus brothers. No better identification of any owner(s) or of local provenance could be gained from the carvings on the covers. Finally, on the front cover, a row of short perpendicular lines alternating with dots is arranged (beginning with 4 lines and 5 dots) to give the numerical sequence: 4-5-2-1-3-1-1-2-2-3-1-2-2-1. This is the set-up of the so-called (in Swedish) Sankt Peders lek (Saint Peter's game, Latin ludus Sancti Petri), i.e. the key to the well-known and popular "Puzzle of the Thirty Counters" (cf. Murphy 1942). This shows once more the author's careful regard for the Swedish model of the runic calendar sticks (see Lithberg 1953, 283-86; Svärdström 1972).

In conclusion, the Vatican rune-book calendar shares the basic traditional characteristics of the Swedish-Estonian production, but proves original in some formal aspects, and more attentive in responding to calendar issues and Swedish models than the average items within the typological class to which it belongs. This group definitely deserves more attention on its own right. Almost immediately after the publication of my article (Cucina 2016a), a fragment of a runic calendar, recently discovered during archaeological excavations in Tartu, was brought to my attention. I will be writing a short notice concerning this new find for a future number of Futhark.

Note that a restricted (or for purchase) PDF file of the article in Italian concerning the Vatican runic calendar, Cucina 2016, is available at: https:// doi.org/10.1400/246649. 


\section{Bibliography}

Bertolini, Ottorino. 1977. "Inventarium codicum vaticanorum latinorum 14.23414.665.” Compiled 1969-75. Typewritten volume in Biblioteca Apostolica Vaticana. Roma.

Bignami-Odier, Jeanne. 1934. "Guide au département des manuscrits de la bibliothèque du Vatican." Mélanges d'archéologie et d'histoire 51: 205-39.

Björnståhl, Jacob Jonas. 1780-84. Resa til Frankrike, Italien, Sweitz, Tyskland, Holland, England, Turkiet, och Grekland. Ed. Carl Christoffer Gjörwell. 6 vols. Stockholm.

Blume, Friederich. 1830. Iter Italicum, vol. 3: Archive, Bibliotheken und Inschriften in der Stadt Rom. Halle.

Brate, Erik. 1908. "Nordens äldre tideräkning." In Inbjudning till öfvervarande af årsexamen vid Högre allmänna läroverket å Södermalm vårterminen 1908, by Olof Örtenblad, 1-28. Stockholm.

Cucina, Carla. 2003. "Olof Celsius a proposito delle rune di Helsingia (da una epistola ad Antonio Magliabechi)." RILD: Rivista italiana di linguistica e dialettologia 5: 33-60.

—. 2016a. "Il calendario runico nella Biblioteca Apostolica Vaticana (Vat. lat. 14613)." Miscellanea Bibliothecae Apostolicae Vaticanae 22: 237-328.

— . 2016b. "Runes in Peripheral Swedish Areas: The Early Ethnographic Literature on Calendar Staves in the Baltic Islands." In Apis matina: Studi in onore di Carlo Santini, ed. Aldo Setaioli, 188-203. Polymnia: Studi di filologia classica, 20. Trieste.

D’Aiuto, Francesco, and Paolo Vian. 2011. Guida ai fondi manoscritti, numismatici, a stampa della Biblioteca Vaticana, vol. 1: Dipartimento manoscritti. Biblioteca Apostolica Vaticana, Studi e testi, 466. Città del Vaticano.

Granlund, Ingalill, and John Granlund. 1973. Lapska ben- och träkalendrar. Nordiska museet, Acta Lapponica, 19. Stockholm.

Hallonquist, Sven-Göran. 1994. "Primstaven: En runalmanacka." In Runmärkt: Från brev till klotter: Runorna under medeltiden, ed. Solbritt Benneth et al., 17793. Stockholm.

Hastrup, Kirsten. 1985. Culture and History in Medieval Iceland: An Anthropological Analysis of Structure and Change. Oxford.

Hofe, Adolf. 1942. "Vier Runenkalender aus dem Naturalienkabinett des Waisenhauses in Halle." Runenberichte 1.4: 135-60, pls. xxii-xxv.

Hupel, August Wilhelm, comp./ed. 1782. Topographische Nachrichten von Liefund Ehstland. Vol. 3. Riga.

Janson, Svante. 2011. "The Icelandic Calendar.” Scripta islandica: Isländska sällskapets årsbok 62: 51-104.

Jansson, Sam Owen. 1962. "De estlandssvenska kalenderstavarna.” Svio-Estonica: Studier utgivna av Svensk-estniska Samfundet 16 (n.s. 7): 126-49.

Jansson, Sven B. F. 1983. De stavlösa runornas tydning. Kungl. Vitterhets Historie och Antikvitets Akademien, Filologiskt arkiv, 30. Stockholm. 
Liebgott, Niels-Knud. 1973. Kalendere: Folkelig tidsregning i Norden. København. Lithberg, Nils. 1921. "Runstavens uppkomst." Fataburen 1921: 1-27.

— . 1932. "Runstaven, en ursvensk rådgivare åt Sveriges bönder." Fataburen 1932: 117-38.

— . 1934. "Kalendariska hjälpmedel.” In Tideräkningen / Tidsregning, ed. Martin P:son Nilsson, 77-93. Nordisk kultur, 21. Stockholm, Oslo, København.

—. 1944. "Månkalender och veckoräckning." Ed. Sifgrid Svensson. Rig 1944: 143-59.

—. 1953. Computus med särskild hänsyn till Runstaven och den Borgerliga Kalendern. Ed. Sam Owen Jansson. Nordiska museet, Handlingar, 29. Stockholm.

Mabillon, Jean, and Michel Germain. 1687. Iter Italicum Litterarium, Annis 1685 et 1686. Luteciae Parisiorum [Paris].

Maliniemi, Aarno. 1925. Der Heiligenkalender Finnlands, seine Zusammensetzung und Entwicklung. Suomen kirkkohistoriallisen seuran toimituksia, 20. Helsingfors.

Malmstedt, Göran. 1994. Helgdagsreduktionen: Övergången från ett medeltida till ett modernt år i Sverige 1300-1800. Historiska institutionen i Göteborg, Avhandlingar, 8. Göteborg.

— . 2014. "In Defence of Holy Days: The Peasantry's Opposition to the Reduction of Holy Days in Early Modern Sweden." Cultural History 3: 103-25.

de Montfaucon, Bernard. 1702. Diarium Italicum sive Monumentorum Veterum: Bibliothecarum Musæorum, \&c.: Notitiæ Singulares in Itinerario Italico Collectæ. Parisiis.

Murphy, Gerard. 1942. "The Puzzle of the Thirty Counters." Béaloideas: fournal of the Folklore of Ireland Society 11: 3-20.

Pfaff, Alfred. 1946. Aus alten Kalendern. Augsburg.

Russwurm, Carl. 1855. Eibofolke oder die Schweden an dem Küsten Ehstlands und auf Runö. Reval.

Russwurm, Carl, and W. McDonald. 1855. Lithographirte Beilagen zu Eibofolke oder die Schweden an dem Küsten Ehstlands und auf Runö. Reval.

Svärdström, Elisabeth. 1966. Nyköpingsstaven och de medeltida kalenderrunorna. Antikvariskt arkiv, 29. Stockholm.

— . 1972. "Lödöserunor som talar och täljer." Fornvännen 67: 94-107.

Tooke, William. 1799. View of the Russian Empire during the Reign of Catharine the Second, and to the Close of the Present Century. Vol. 1. London.

Urban, Sylvanus, and William Tooke. 1812. "Explanation of an Almanac Used in the Isle of Esel." Gentleman's Magazine and Historical Chronicle 82: 625-26, pl.

Futhark 9-10 (2018-2019) 